\title{
NATURAL DURABILITY OF Cupressus lusitanica, Cryptomeria japonica AND Pinus taeda WOODS IN FIELD TRIAL
}

\author{
Magnos Alan Vivian ${ }^{1 *}$, Gláucia Cota Nunes ${ }^{1}$, Mário Dobner Jr. ${ }^{1}$, Karina Soares Modes ${ }^{1}$, Évelyn Janaina \\ Grosskopf $^{1}$, Ugo Leandro Belini ${ }^{2}$
}

${ }^{1}$ Universidade Federal de Santa Catarina, Departamento de Agricultura, Biodiversidade e Florestas, Curitibanos, Santa Catarina, Brasil *magnos.alan@ufsc.br, glauciacota@gmail.com, mario.dobner@ufsc.br, karina.modes@ufsc.br, evellyngrosskopf@gmail.com ${ }^{2}$ Universidade Tecnológica Federal do Paraná, Departamento de Desenho Industrial, Programa de Pós Graduação em Engenharia Mecânica e de Materiais, Programa de Pós Graduação em Sustentabilidade Ambiental Urbana, Curitiba, Paraná, Brasil - ubelini@utfpr.edu.br

Received for publication: 19/02/2019 - Accepted for publication: 19/04/2019

\begin{abstract}
Resumo
Durabilidade natural das madeiras de Cupressus lusitanica, Cryptomeria japonica e Pinus taeda em ensaio de campo. $\mathrm{O}$ objetivo do presente estudo foi avaliar a durabilidade natural das madeiras de Cupressus lusitanica, Cryptomeria japonica e Pinus taeda submetidas a ensaio de campo de apodrecimento, através da perda de massa e índice de deterioração. O experimento foi conduzido em campo aberto no município de Curitibanos/SC, por um período de 24 meses, com avaliações realizadas a cada 6 meses. Para condução do estudo utilizou-se as madeiras das espécies de Cupressus lusitanica (16 anos), Cryptomeria japonica (16 anos) e Pinus taeda (madeira juvenil $=15$ anos e adulta $>30$ anos) das quais foram confeccionados corpos de prova com as dimensões de 2,5 x 5,0 x 50,0 cm, de espessura, largura e comprimento, respectivamente, seguindo o padrão sugerido pela IUFRO. Após 24 meses de exposição ao campo de apodrecimento à madeira das espécies $C$. japonica e $C$. lusitanica apresentaram índice de deterioração que refletiu ataque evidente, porém moderado de fungos e térmitas, enquanto as madeiras de $P$. taeda (juvenil) e $P$. taeda (adulta) apresentaram índice de deterioração que refletiu em apodrecimento intenso ou ataque intenso de térmitas. Em relação à perda de massa as madeiras de $C$. japonica e $C$. lusitanica foram classificadas como altamente resistentes, a madeira de $P$. taeda (juvenil) foi considerada resistente e a madeira de $P$. taeda (adulta) foi considerada como moderadamente resistente. De maneira geral, as madeiras de $C$. lusitanica e $C$. japonica apresentaram maior durabilidade natural quando utilizadas em contato com o solo.

Palavras-chave: Apodrecimento, biodeterioração, degradação natural.
\end{abstract}

\section{Abstract}

The purpose of this study was to evaluate the natural durability of Cupressus lusitanica, Cryptomeria japonica and Pinus taeda woods subjected to a rotting field trial, through mass loss and deterioration index. The trial was conducted in an open field in the city of Curitibanos, State of Santa Catarina, Brazil, for a 24-month period, with evaluations carried out every 6 months. For developing the study, we used the woods of Cupressus lusitanica (16 years), Cryptomeria japonica (16 years) and Pinus taeda (juvenile $=15$ years and mature wood $>30$ years) species, from which test specimens were made with the dimensions of $2.5 \times 5.0 \times 50.0 \mathrm{~cm}$ in thickness, width and length, respectively, following the standards suggested by IUFRO. After 24 months of exposure to the rotting field the woods of $C$. japonica and $C$. lusitanica species showed a deterioration index that reflected an evident but moderate attack of fungi and termites, while the woods of $P$. taeda (juvenile) and $P$. taeda (mature) showed deterioration index that reflected an intense rotting and intense attack of termites. Regarding the mass loss the woods of $C$. japonica and $C$. lusitanica were classified as highly resistant, while $P$. taeda (juvenile) was considered resistant and P. taeda (mature) was considered moderately resistant. In general, the woods of $C$. lusitanica and $C$. japonica showed greater natural durability when used in contact with the soil.

Keywords: rotting, biodeterioration, natural degradation.

\section{INTRODUCTION}

The Brazilian forestry sector contributes significantly to the country's economy, and generated a sectorial gross domestic product (GDP) of R\$ 86.6 billion in 2018, with an increase of 13\% over the previous year (IBÁ, 2019). The latest estimate indicates that the country has 7.83 million hectares of planted forests, which are responsible for supplying more than $90 \%$ of the wood intended to the various forest segments (IBÁ, 2019).

Wood is widely used because it has numerous interesting characteristics, such as easy handling, high mechanical strength, capacity to be a thermal and acoustic insulator, in addition to the most diverse aromas, colors and textures, which make it very desired by man since the beginnings of humanity (APRILE et al., 1999).

FLORESTA, Curitiba, PR, v. 50, n. 3, p. 1603 - 1612, jul/set 2020.

Vivian, M. A. et.al.

ISSN eletrônico 1982-4688 
However, one characteristic in particular will affect its use, its natural durability, especially in tropical countries, such as Brazil, with great climatic variation and xylophages among its regions. According to Jesus et al. (1988), the knowledge of this characteristic helps in the choice of timber species that can be used in environments where they will be subject to damages caused by climatic and abiotic factors and a diversity of xylophagous agents (biotics) present in the environment, especially in direct contact with the soil. Therefore, according to Melo et al. (2010), the knowledge of its natural durability, and also of the places where the wood can be used, will avoid wastes and expenses due to the pieces replacement.

In order to evaluate the wood natural durability, one of the most used tests are the "rotting fields", subjecting wood to external environments in direct contact with the soil, being exposed to irregular cycles of leaching, sun exposure, drying, chemicals and xylophages present in the soil, which can act together in the wood deterioration (COSTA et al., 2005). In addition to field tests, there are laboratory tests, which allow greater control of the optimal development conditions of xylophages (temperature, humidity and photoperiod), therefore providing intense attacks, and consequently providing faster results.

According to Araújo et al. (2012) in view of the scarcity of high natural durability species supply from native forests, due to environmental issues, it is not possible to meet the demand for these woods, which are practically depleted. When they still can be extracted, respecting the supply and demand law, the commercial value of these species has been increasing, and their use is economically impracticable. Therefore, according to this perspective to meet the current and future demand for wood products, the only safe source is in planted forests, using fast-growing species that are managed for a self-sustainable production.

In this scenario, several species/genus with great potential for large-scale cultivation emerge, some are already a reality in the forestry industry, such as Pinus and Eucalyptus genus, which together represent $92 \%$ of the planted area in the country (IBÁ, 2019), and some others also deserve attention, such as Cupressus and Cryptomeria genus.

Today the Southern region has its forest base focused on the Pinus genus, which has rapid growth and resistance to the cold weather of this region. However, based on the studies reported in the literature (COSTA et al., 2005; SCHEFFER \& MORRELL, 1998), the wood of this genus has a low natural durability, especially when used in contact with the soil. And seeking to provide subsidies to new alternatives, the Cupressus and Cryptomeria genus arise, which like Pinus, are conifers and adapt very well to the region conditions.

In Cupressus genus the Cupressus lusitanica species stands out, which is popularly known as cypress, and in the Cryptomeria genus there is the Cryptomeria japonica, also called Japanese cedar. Both have a great potential for cultivation in the Southern region of Brazil, but the real quality of their wood is still unknown, especially concerning their natural durability. Carneiro et al. (2009) and Okino et al. (2010) mention the great adaptive and growing potential of $C$. japonica and $C$. lusitanica to the conditions of the Santa Catarina Plateau.

Therefore, with the scarcity of technical information on the natural resistance of these species wood, we sought to infer, based on field tests, which is the durability level of these species, in order to find new alternatives for more severe uses of wood, especially in contact with the soil. Consequently, the purpose of this study was to evaluate the natural durability of $C$. lusitanica, $C$. japonica and $P$. taeda woods subjected to a rotting field trial.

\section{MATERIAL AND METHODS}

\section{Used species}

In order to develop the study, the woods of $P$. taeda, with juvenile wood (up to 15 years) from a plantation located in the city of Campo Belo do Sul/SC, with spacing of $3.0 \times 2.0 \mathrm{~m}(1,600$ trees/ha), and the mature wood (with 43 years of age, using the wood portion above the $30^{\text {th }}$ growth ring), obtained from a plantation in the city of Correia Pinto/SC, with spacing of $2.0 \times 2.0 \mathrm{~m}$ (2,500 trees/ha) were used. And the C. lusitanica and C. japonica, both juvenile wood (16 years), were obtained from experimental forest stands from Florestal Gateados Ltda. implemented in the city of Campo Belo do Sul/SC, with spacing of $2.5 \times 2.0 \mathrm{~m}$ (2,000 trees/ha).

For this study, 10 trees of each species were used, from which the first log with 1.30 meters in length (between base and diameter at breast height) was removed to obtain a specimens. From each species, 55 defectfree test specimens were made, in the dimensions of $2.5 \times 5.0 \times 50.0 \mathrm{~cm}$ in thickness, width and length, according to the IUFRO (International Union for Forestry Research Organization) standards, as mentioned by Lepage (1970). Then they were dried in a commercial kiln in order to reduce the wood moisture (between 15 and 20\%) so that the specimens could be sanded for a better finishing.

In order to obtain the initial mass (Mi) the test specimens were subjected to drying in a laboratory oven, with forced air circulation, at a temperature of $60{ }^{\circ} \mathrm{C}$ until obtaining a constant weight. Subsequently, they were weighed on a precision scale, and their dimensions were measured using a ruler and a digital caliper to calculate the volume. With the mass and volume values, the wood density was calculated, after drying at $60{ }^{\circ} \mathrm{C}$, using Equation 1 to assist in the results discussion.

FLORESTA, Curitiba, PR, v. 50, n. 3, p. 1603 - 1612, jul/set 2020. 


$$
\mathrm{D}=\frac{\mathrm{m}}{\mathrm{v}}
$$

where: $\mathrm{D}$ is the density $\left(\mathrm{g} / \mathrm{cm}^{3}\right), \mathrm{m}$ is the mass $(\mathrm{g})$ and $\mathrm{v}$ is the volume $\left(\mathrm{cm}^{3}\right)$.

The mass obtained from the weighing was called initial mass and served as the basis for calculating the mass loss after exposure to the rotting field.

\section{Rotting field installation}

The rotting field was installed in December 2015, in an open field in the Experimental Forest Area belonging to the Federal University of Santa Catarina (UFSC), in the city of Curitibanos, State of Santa Catarina, Brazil, at latitude and longitude of $27^{\circ} 18^{\prime} 52.11^{\prime \prime S}$ and $50^{\circ} 42^{\prime} 36.36$ "O, respectively, at an altitude of 835 meters. According to Köppen's classification, the region climate is $\mathrm{Cfb}$ - humid subtropical with mild summers (EMBRAPA, 2012). The rotting field was established in $73.5 \mathrm{~m}^{2}(9.8 \times 7.5 \mathrm{~m})$ of total area, where cleaning and maintenance were performed periodically (monthly).

The experiment was conducted in a randomized block design (DBC), using plots subdivided in time, with 5 blocks with 10 test specimens of each species per block, as shown in the drawing of Figure 1. Test specimens were installed in the soil $30 \mathrm{~cm}$ equidistant between each other and $100 \mathrm{~cm}$ between the blocks, and were buried up to half their length (depth of $25 \mathrm{~cm}$ ), the region known as outcrop zone, usually the most affected.

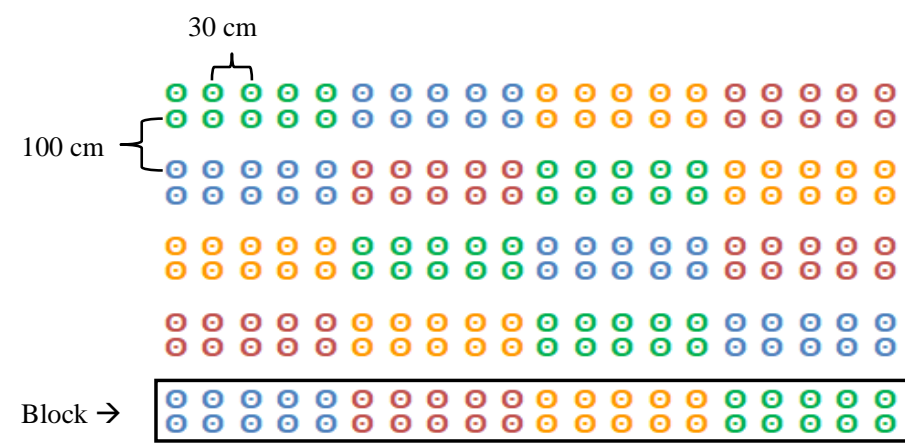
$\odot$ C. japonica
$\odot \quad$ C. lusitanica
$\odot \quad$ P. taeda (Juvenile)
$\odot \quad$ P. taeda (Mature)

Figure 1. Sketch of rotting field.

Figura 1. Croqui do campo de apodrecimento.

\section{Analysis of climatic conditions in the period and fungal attack potential}

As they are variables that can influence the biodeterioration intensity, climatic data such as temperature, humidity and rainfall rates of Curitibanos region were collected during the experiment period, at the meteorological station located at UFSC campus, in the city of Curitibanos, at 1,097 meters of altitude.

Based on the meteorological data, the fungal attack potential (FAP) of the region was calculated, according to Equation 2, developed by Scheffer (1971) and adapted to the conditions in Brazil by Martins et al. (2003).

$$
\mathrm{FAP}=\sum_{\text {january }}^{\text {december }} \frac{[(\mathrm{T}-2) \cdot(\mathrm{D}-3)]}{16,7}
$$

where: FAP is the fungal attack potential, $\mathrm{T}$ is the average temperature $\left({ }^{\circ} \mathrm{C}\right), \mathrm{D}$ is the number of days in the month with rainfall equal to or greater than $0.30 \mathrm{~mm}$.

\section{Natural durability evaluation}

The woods natural durability was evaluated by visual analysis (deterioration index), as proposed by Lepage (1970), and by the mass loss after exposure to the field. Periodically, every 6 months, in June and December, for 2 years after the experiment installation, 5 test specimens per species were evaluated, one per block as shown in Figure 1. They were systematically removed and over the course of the two years 20 test specimens were inspected per species.

The test specimen inspection began with the application of a slight impact with the hands on the exposed part of the stake while still in the ground. According to Lepage (1970) this procedure aims to find out if the loss of resistance was able to cause the stake breaking. Test specimens that showed no rupture were carefully removed.

FLORESTA, Curitiba, PR, v. 50, n. 3, p. 1603 - 1612, jul/set 2020.

Vivian, M. A. et.al.

ISSN eletrônico 1982-4688 
After removal, samples were cleaned using a soft bristle brush to remove all adhered soil, a procedure necessary to facilitate its visual evaluation and not influence the mass loss results.

The deterioration index consisted of a visual analysis assigning scores to the test specimens from the field at each evaluation period, according to the classification shown in Table 1, as proposed by Lepage (1970).

Table 1. Classification of wood deterioration by visual index.

Tabela 1. Classificação da deterioração da madeira pelo índice visual.

\begin{tabular}{lc}
\hline \multicolumn{1}{c}{ Wood aspect } & Deterioration index \\
\hline Strong, no attack & 100 \\
Slight or superficial attack of fungi and termites & 90 \\
Evident but moderate attack of fungi and termites & 70 \\
Intense decay or intense termite attack & 40 \\
Break, almost total loss of resistance & 0 \\
\hline
\end{tabular}

Fonte: Adapted by Lepage (1970).

Two independent evaluators (in order to reduce the error given that it is a subjective analysis) made the analysis of the five samples collected from each species per period (one test specimen per species, of each of the five blocks), and from the results the deterioration index mean was obtained.

In order to determine the mass loss, after each period the removed samples were subjected to storage using a laboratory oven with forced circulation at $60{ }^{\circ} \mathrm{C}$ until obtaining constant mass. Then the stacks were weighed on a precision scale, obtaining the final mass (Mf). Based on the samples initial and final mass, the mass loss was calculated using Equation 3, in order to classify the resistance class, according to ASTM D 2017-05 standard (2005). This standard refers to accelerated rotting tests in the laboratory, but as there are no standards for field tests it was decided to use it to have a basis for comparing the woods resistance.

$$
\operatorname{ML}(\%)=\frac{\mathrm{Mi}-\mathrm{Mf}}{\mathrm{Mi}} \times 100
$$

where: ML is the mass loss (\%), Mi é is the initial mass (g) and Mf is the final mass ( $\mathrm{g})$.

\section{Statistical analysis}

The data obtained from the experiment were tabulated and processed using Microsoft Office Excel 2010. For statistical analysis, the R studio software was used. To perform the density statistical analysis, a completely randomized design (DIC) was used. The rotting field was installed with a randomized block design (DBC), with plots subdivided over time, which was evaluated by analysis of variance (ANOVA) and Tukey mean test, with $95 \%$ of confidence probability.

\section{RESULTS}

Density Table 2 .

The wood density of $C$. japonica, $C$. lusitanica and $P$. taeda (juvenile and mature) can be observed in

Table 2. Density of wood used.

Tabela 2. Densidade das madeiras utilizadas.

\begin{tabular}{cc}
\hline Species & Density $\left(\mathbf{g} / \mathbf{c m}^{\mathbf{3}}\right)$ \\
\hline C. lusitanica & $0.429^{\mathrm{B}}$ \\
C. japonica & $0.328^{\mathrm{D}}$ \\
P. taeda (Juvenile) & $0.399^{\mathrm{C}}$ \\
P. taeda (Mature) & $0.553^{\mathrm{A}}$ \\
\hline
\end{tabular}

Averages followed by the same letter, do not present a statistically significant difference by means test (Tukey, p>0.05).

The density of the woods used varied significantly between the species and type of wood as it can be seen in Table 2. These values served to compare the species. The wood of P. taeda (mature) was the one that showed the significantly higher value, followed by $C$. lusitanica, $P$ taeda (juvenile) and $C$. japonica.

FLORESTA, Curitiba, PR, v. 50, n. 3, p. 1603 - 1612, jul/set 2020.

Vivian, M. A. et.al.

ISSN eletrônico 1982-4688 


\section{Climatic conditions and fungal attack potential}

Figure 2 shows the average fungal attack potential (FAP) of the field test run period.

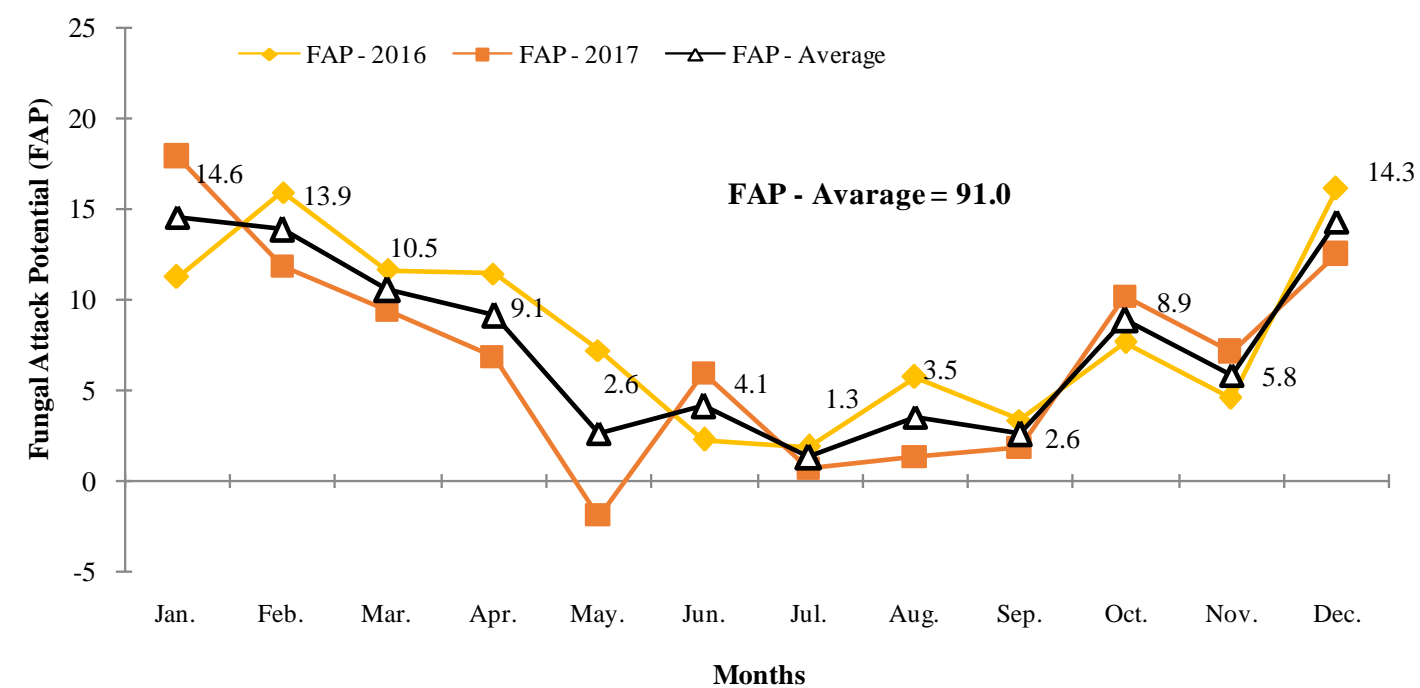

Figure 2. Fungal Attack Potential (FAP) during the evaluated period.

Figura 2. Potencial de Ataque Fúngico (PAF) durante o período avaliado.

The rainfall days counting in 2016 and 2017, considering a precipitation level equal to or greater than $0.30 \mathrm{~mm}$, was 149 and 129, respectively. And the annual accumulated rainfall was 1,894.6 mm in 2016, and $1,025.8 \mathrm{~mm}$ in 2017 . The average temperatures calculated in 2016 and 2017 were 16.7 and $16.4^{\circ} \mathrm{C}$, respectively.

The accumulated FAP based on the measurements performed in the trial period for the years 2016 and 2017 were 98.7 and 83.3, respectively. Therefore, the average for Curitibanos region in the trial period was 91.0.

\section{Natural durability evaluation}

The deterioration index of the woods exposed to the rotting field can be observed in Figure 3 , which exposes how much each species showed wear over the exposure time. Over time we can observe that there was a reduction in the index for all species, indicating that wood wear was occurring, as it can be seen in Figure 4.

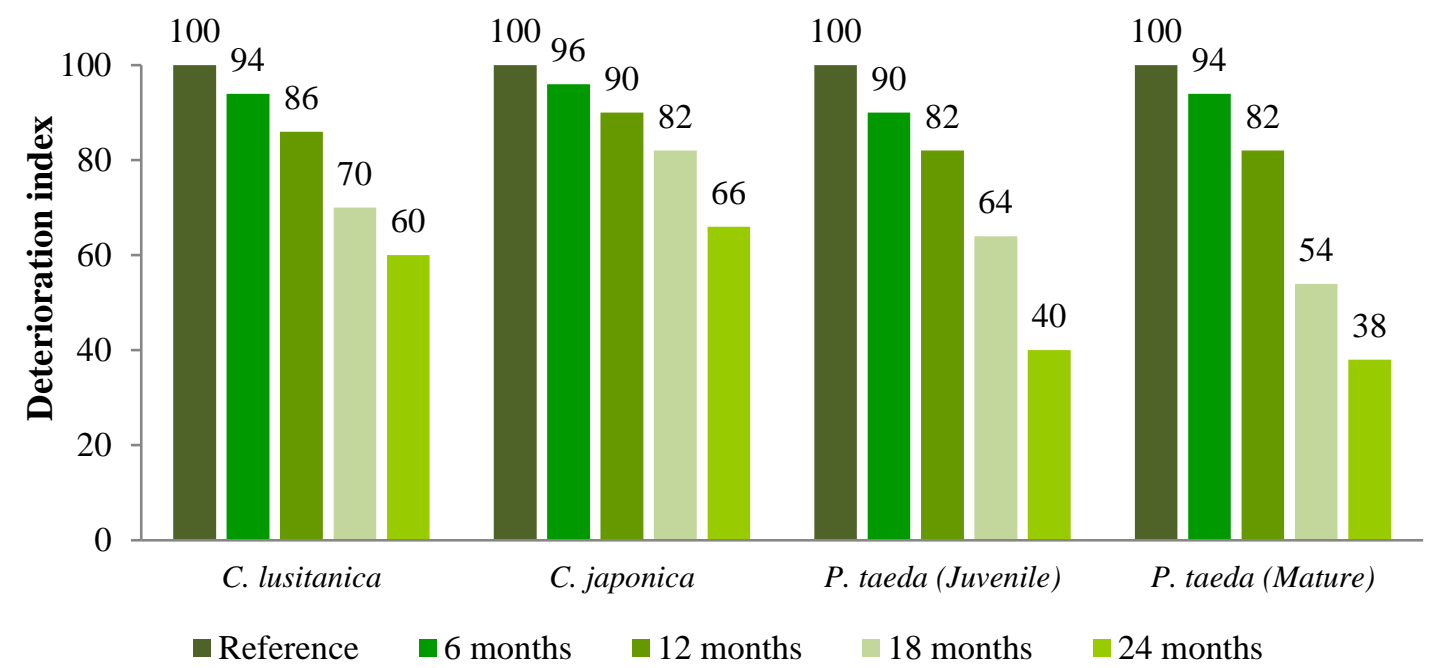

Figure 3. Deterioration index of the specimens submitted to the rotting field.

Figura 3. Índice de deterioração dos corpos de prova submetidos ao campo de apodrecimento.

FLORESTA, Curitiba, PR, v. 50, n. 3, p. 1603 - 1612, jul/set 2020.

Vivian, M. A. et.al.

ISSN eletrônico 1982-4688 
According to Table 3, during the first 12 months of the experiment, the results obtained in the species deterioration index did not differ statistically from each other, indicating in this period that the woods suffered light or superficial attacks of fungi and termites. Even though there was no statistical difference between species, C. japonica was the species that showed the lowest surface degradation, slightly changing its appearance, followed by $C$. lusitanica species. On the other hand, juvenile and mature $P$. taeda species showed a greater surface wear, resulting in a lower index value.

Table 3. Deterioration index of the specimens submitted to the rotting field.

Tabela 3. Índice de deterioração dos corpos de prova submetidos ao campo de apodrecimento.

\begin{tabular}{cccccc}
\hline \multicolumn{2}{c}{ Evaluations } & \multicolumn{4}{c}{ Species } \\
\hline $\mathrm{N}^{\mathrm{o}}$ & Months & C. lusitanica & C. japonica & $\begin{array}{c}\text { P. taeda } \\
\text { (Juvenile) }\end{array}$ & $\begin{array}{c}\text { P. taeda } \\
\text { (Mature) }\end{array}$ \\
\hline 1 & 6 & $94^{\mathrm{Aa}}$ & $96^{\mathrm{Aa}}$ & $90^{\mathrm{Aa}}$ & $94^{\mathrm{Aa}}$ \\
2 & 12 & $86^{\mathrm{Aab}}$ & $90^{\mathrm{Aa}}$ & $82^{\mathrm{Aab}}$ & $82^{\mathrm{Aab}}$ \\
3 & 18 & $70^{\mathrm{Aab}}$ & $82^{\mathrm{Aab}}$ & $64^{\mathrm{Ab}}$ & $54^{\mathrm{Abc}}$ \\
4 & 24 & $60^{\mathrm{Ab}}$ & $66^{\mathrm{Ab}}$ & $40^{\mathrm{Ac}}$ & $38^{\mathrm{Ac}}$ \\
\hline
\end{tabular}

Averages followed by the same letter, lower case in the column or upper case in the line, do not show statistically significant variation by means test (Tukey, $\mathrm{p}>0.05$ ).

In the 24-month exposure evaluations, the visual index for the $C$. japonica and $C$. lusitanica species indicated an evident, but moderate attack of fungi and termites, while the woods of $P$. taeda (juvenile) and $P$. taeda (mature) indicated an intense rotting or intense attack of termites, as it can be seen in Figure 4 . This can be justified by the presence of soil termites in the surrounding area.

What was also possible to observe is that after the field exposure, test specimens underwent a very noticeable change in natural color, and the wood was becoming with an aged aspect, with shades of gray. All species showed the same darkening pattern, but it was more marked in P. taeda wood (both juvenile and mature).
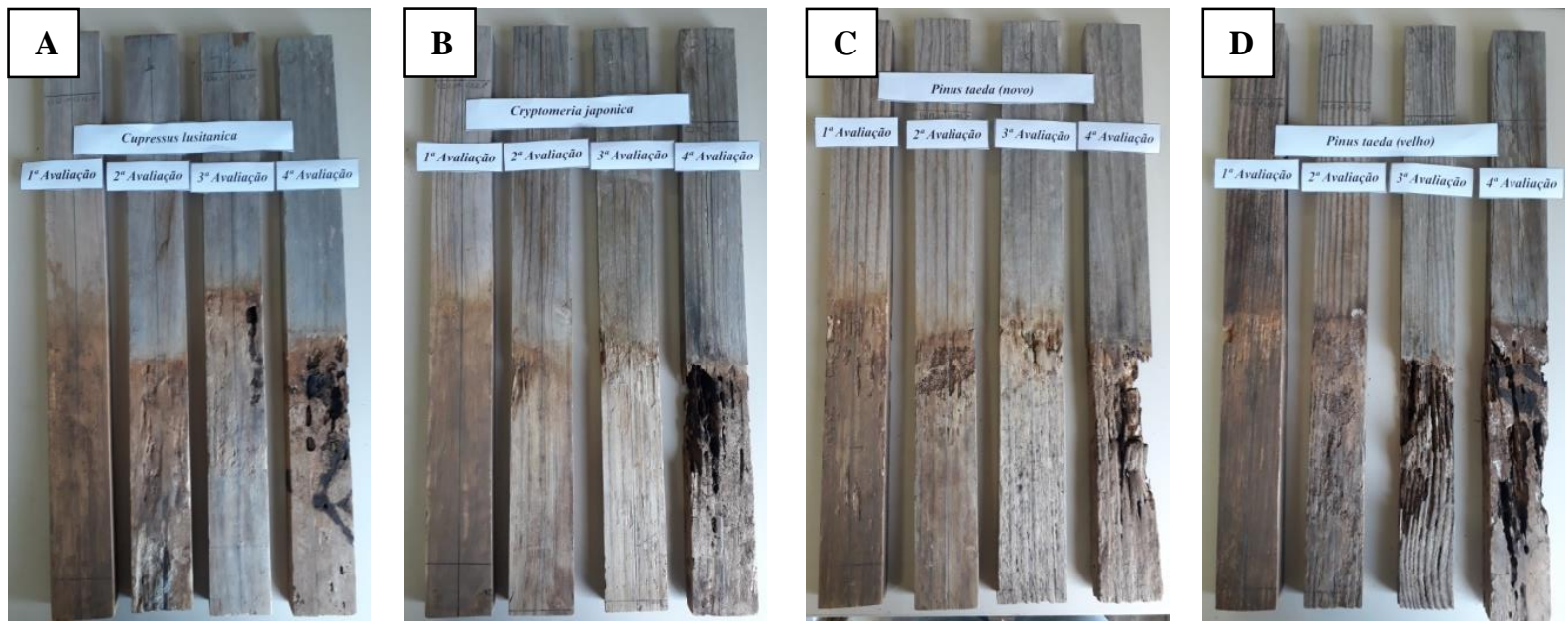

Figure 4. Wood of C. lusitanica (A), C. japonica (B), P. taeda (juvenile) (C), P. taeda (mature) (D) after exposure to field.

Figura 4. Madeira de C. lusitanica (A), C. japonica (B), P. taeda (juvenil) (C), P. taeda (adulto) (D) após exposição a campo.

The wood mass loss after exposure to the rotting field can be seen in Table 4 .

Table 4. Mass loss (\%) of the specimens submitted to the rotting field.

Tabela 4. Perda de massa (\%) dos corpos de prova submetidos ao campo de apodrecimento.

\begin{tabular}{cccccc}
\hline \multicolumn{2}{c}{ Evaluations } & \multicolumn{3}{c}{ Species } \\
\hline \multirow{2}{*}{$\mathrm{N}^{\mathrm{o}}$} & \multirow{2}{*}{ Months } & C. lusitanica & C. japonica & $\begin{array}{c}\text { P. taeda } \\
\text { (Juvenile) }\end{array}$ & $\begin{array}{c}\text { P. taeda } \\
\text { (Mature) }\end{array}$ \\
\hline 1 & 6 & $1.84^{\mathrm{Aa}}$ & $1.33^{\mathrm{Aa}}$ & $2.87^{\mathrm{Aa}}$ & $4.25^{\mathrm{Aa}}$ \\
2 & 12 & $3.69^{\mathrm{Aa}}$ & $3.80^{\mathrm{Aa}}$ & $4.92^{\mathrm{Aab}}$ & $9.05^{\mathrm{Aa}}$ \\
3 & 18 & $4.89^{\mathrm{Aa}}$ & $4.58^{\mathrm{Aa}}$ & $8.55^{\mathrm{Ab}}$ & $22.30^{\mathrm{Bb}}$ \\
4 & 24 & $7.42^{\mathrm{Aa}}$ & $7.57^{\mathrm{Aa}}$ & $14.94^{\mathrm{Bb}}$ & $26.42^{\mathrm{Cb}}$ \\
\hline
\end{tabular}

Averages followed by the same letter, lower case in the column or upper case in the line, do not show statistically significant variation by means test (Tukey, $\mathrm{p}>0.05$ ).

FLORESTA, Curitiba, PR, v. 50, n. 3, p. 1603 - 1612, jul/set 2020.

Vivian, M. A. et.al.

ISSN eletrônico 1982-4688 
Although the woods of $C$. japonica and $C$. lusitanica showed densities with statistical differences (Table 2), regarding the mass loss there was no difference between them, and both obtained a lower mass loss. On the other hand, $P$. taeda (mature) wood showed the highest density among the species, and also the highest mass loss, surpassing the same species with juvenile wood.

It was observed that the woods performance in the first 12 months of the experiment showed no statistical difference between the species/wood, but from the third evaluation (18 months) the wood of $P$. taeda (mature) showed greater mass loss, with significant differences compared to the others. After the 24-months exposure the mass loss of $P$. taeda (mature) was intensified, followed by $P$. taeda (juvenile), $C$. japonica and $C$. lusitanica, and the latter two showed no significant difference between each other.

After two years (24 months) of field exposure, the woods could be classified, based on the resistance class of ASTM D 2017-5 (2005) standard, as follows: $P$. taeda (mature) = moderately resistant (ML=26.42\%); P. taeda (juvenile $)=$ resistant $(\mathrm{ML}=14.94 \%) ; C$. lusitanica $=$ highly resistant $(\mathrm{ML}=7.42 \%) ;$. japonica $=$ highly resistant $(\mathrm{ML}=7.57 \%)$.

\section{DISCUSSION}

\section{Climatic conditions and fungal attack potential}

The mean FAP observed during the experiment (91.0) is within the range mentioned by Martins et al. (2003), which established FAP values in the range of 70.00 to 120.00 for most of the territory of Santa Catarina.

We observed that the months with the lowest FAP were between May and September, because in addition to little rainfall, the average temperature in these months decreased, so it is evident that there is a lower probability of attacks by xylophagous agents in periods with lower rainfall rates and lower temperatures. In the months from December to February, due to high temperatures and rainfall level, the highest values for the FAP were observed, indicating that in this period there is a higher risk of fungal attacks in woods.

Casavecchia et al. (2016) mention that the highest probability of fungal attack is in the rainy season, and in this period more attention should be given to the drying and storage of wood. The same authors also mention that the highest and lowest FAP for the state of Mato Grosso are in January and July, respectively. This same trend was observed for the state of Santa Catarina (in the city of Curitibanos), according to Figure 2.

When it is said that wood is susceptible to xylophages attack, that does not mean that in all uses it will be at risk, the susceptibility of the wood is influenced by other factors, such as the moisture content which the wood is exposed to, the use period (and also the use situation, such as internal or external, with or without contact with soil, etc.), in addition to the use region, because the presence of xylophages is influenced by environmental variables, such as temperature and rainfall.

\section{Natural durability evaluation}

In a study conducted by Costa et al. (2005), the fence posts of Pinus elliottii, after 3 years of the rotting field implementation, showed a deterioration index equal to zero, indicating that the natural durability of the species is approximately 3 years in the Cerrado region.

In the case of the wood color change, according to Ritter \& Morrell (1990) this effect occurs due to the photochemical degradation that is promoted by the action of ultraviolet rays, which act mainly on lignin, on the outside of the wood, causing the tissue discoloration, and providing a grayish aspect. Due to the change in humidity (rain and sun) these woods also suffered surface cracks that facilitate the entry of xylophages, such as fungi and termites, which are naturally present in the soil.

This change in color was also observed in a trial conducted by Vivian et al. (2014) with Eucalyptus grandis and Eucalyptus cloeziana woods exposed to open field, which showed aging, while the samples that were exposed in the forest the aspect was normal, and can evidence that direct radiation causes photochemical degradation, causing aging.

A justification for mature wood ( $P$. taeda mature) having presented a greater mass loss can be due to the lower amount of extractives. A study conducted by Yeh et al. (2006) showed that the amount of extractives present in the juvenile wood of P. taeda was $3.3 \%$ and in mature wood $2.5 \%$.

British Standard (1994) classifies the heartwood (physiologically inactive portion of the trunk, which usually shows extractive deposition, and makes it more resistant to biodegradation) of $P$. taeda as non-durable to the attack of fungi and as susceptible to the attack of termites and coleoptera of Hylotrupes bajulus and Anobium punctatum species. Gomes et al. (2005) mention that the natural durability of the species of Pinus cariebea var. hondurensis, evaluated in the field in the city of Belém/PA, was little durable, since it did not resist 12 months in contact with the soil. 
The results obtained for the $C$. lusitanica wood, which was considered highly resistant, are consistent with those found by Jones et al. (2013), which after performing laboratory tests concluded that $C$. lusitanica wood was resistant to the Gloephyllum trabeum and Trametes versicolor fungi, but was less resistant to the Coniophora puteana fungi. However, the mass loss in none of the cases exceeded $6 \%$, and was classified as very durable or highly resistant.

After 12 weeks in a laboratory trial conducted by Mohareb et al. (2010) the test specimens of $C$. lusitanica showed a mass loss of $2 \%$, and in the same trial they also concluded that the extractives present in the heartwood of $C$. lusitanica are responsible for the wood resistance to biodegradation, because by performing the removal of extractives from the heartwood, the material was greatly degraded by the Postia placenta fungi, so concluding that these extractives act as natural biocides.

In an accelerated rotting trial conducted by Okino et al. (2009) the Cupressus sp. and C. glauca species with 25 and 17 years, respectively, were resistant to Phanerochaete chrysosporium e and Gloephyllum striatum fungi. The same authors mention that due to the presence of tropolone compounds in extractives, the woods of the Cupressaceae family are protected from rotting insects and fungi. Therefore, according to Low et al. (2005), the heartwood of $C$. lusitanica when used above ground is quite durable, resisting the attack of insects and fungi, while the sapwood, according to Shimizu et al. (2006) is quite susceptible to xylophagous attack and rotting. We point out that to use the sapwood more effectively, where it is desired that the wood is durable for longer, it is necessary to perform preserving treatments.

Scheffer \& Morrell (1998) describe conflicts concerning the durability of $C$. lusitanica wood in the literature, because some mention it as resistant, while others mention it as very resistant. This fact may be due to the weathering and drying process of the wood, which can affect the extractive content due to the evaporation of volatile compounds, which can cause changes in its natural durability (MOHAREB et al., 2010).

Regarding C. japonica wood, which was classified as highly resistant in this study, BIS-401 (2001) mentions that this wood is resistant in contact with the soil for a period of up to 60 months of exposure.

\section{CONCLUSIONS}

Based on the observed results, we conclude that:

- According to the FAP of the region obtained during the exposure period, the months of May to September are less conducive to biological deterioration, and the months of December to February are the most conducive to biological deterioration.

- $\quad$ Based on the mass loss, after the 24-month exposure to the rotting field, $C$. japonica and $C$. lusitanica woods are classified as highly resistant, $P$. taeda (juvenile) wood is considered resistant, and $P$. taeda (mature) wood is considered moderately resistant.

- After the 24-month exposure to the rotting field, $C$. japonica and $C$. lusitanica species showed index that reflect in moderate biological deterioration, while $P$. taeda (juvenile) and $P$. taeda (mature) woods showed rates that reflect an intense deterioration.

- $\quad$. lusitanica and C. japonica woods have greater natural durability in contact with the soil and in open environment, and therefore they can be used outdoors with greater safety when compared to P. taeda wood.

\section{REFERENCES}

AMERICAN SOCIETY FOR TESTING AND MATERIALS. ASTM D-2017. Standard test method for accelerated laboratory test of natural decay resistance of wood. Philadelphia, 2005. 5p.

APRILE, F. M.; DELITTI, W. B. C.; BIANCHINI JR., L. Aspectos cinéticos da degradação de laminados de madeira em ambientes aquático e terrestre. Revista Brasileira de Biologia, Rio de Janeiro, v.59, n.3, p. 485 - 492, 1999.

ARAÚJO, H. J. B.; MAGALHÃES, W. L. E.; OLIVEIRA, L. C. Durabilidade de madeira de eucalipto citriodora (Corymbia citriodora (Hook.) K.D. Hill \& L.A.S. Johnson) tratada com CCA em ambiente amazônico. Acta Amazônica, Manaus, v. 42, n. 1, p. 49-58. 2012.

BOREAL OF INDIAN STANDARDS. BIS-401:2001. Indian Standard. Preservation of timbers: Code of practice for. New Delhi, p. 25, 2001.

BRITISH STANDARD- BS. EN 350 - 2: 1994. Durability of wood and wood-based products - Natural durability of solid wood: Part 2: Guide to natural durability and treatability of selected wood species of importance in Europe. European Committee for Standardization, 1994.

FLORESTA, Curitiba, PR, v. 50, n. 3, p. 1603 - 1612, jul/set 2020.

Vivian, M. A. et.al.

ISSN eletrônico 1982-4688

DOI: $10.5380 /$ rf.v50 i3. 65059 
CARNEIRO, M. E.; BITTENTCOURT, E.; MUNIZ, G. I. B. Qualidade da madeira de Cryptomeria japonica D. Don. Floresta, Curitiba, v. 39, n. 4, p. 913-920, 2009.

CASAVECCHIA, B. H.; SOUZA, A. P.; STANGERLIN, D. M.; MELO, R. R. Potential fungal attack for wood in Mato Grosso state, Brazil. Nativa, Sinop, v. 4, n. 3, p. 156-161, 2016.

COSTA, A. F.; VALE, A. T.; GONZALEZ, J. C.; SOUZA, F. D. M. Durabilidade de madeiras tratadas e não tratadas em campo de apodrecimento. Floresta e Ambiente, Seropédica, v. 12, n. 1, p. 7-14, 2005.

EMPRESA BRASILEIRA DE PESQUISA AGROPECUÁRIA - EMBRAPA. Atlas climático da Região Sul do Brasil: Estados do Paraná, Santa Catarina e Rio Grande do Sul. $2^{a}$ edição, Pelotas: Embrapa Clima Temperado; Colombo: Embrapa Florestas, 333 p. 2012.

GOMES, J. I.; SILVA, E. M. A.; MELO, A. T. S. Durabilidade de 15 espécies de madeiras amazônicas em contato com o solo em ambiente sombreado. Belém: Embrapa Amazônia Oriental; 2005. 4 p. (Comunicado técnico, 148).

INDÚSTRIA BRASILEIRA DE ÁRVORES: IBÁ. Relatório 2019, São Paulo: IBÁ, 2019. 80p.

JESUS, M. A.; MORAIS, J. W.; ABREU, R. L. S.; CARDIAS, M. F. C. Durabilidade natural de 46 espécies de madeiras amazônicas em contato com o solo em ambiente florestal. Scientia Forestalis, Piracicaba, n. 54, p. 8191, 1998.

JONES, T. G.; LOW, C. B., MEDER, R.; O'CALLAHAN, D. R.; MILNE, P. G.; CHITTENDEN, C. M.; EBDON, N.; DUNGEY, H.S. Heartwood of Cupressus lusitanica, C. macrocarpa, Leyland and Ovens cypress and prediction of its durability using near-infrared spectroscopy. European Journal of Wood and Wood Products, v. 71, p. 183-192, 2013.

LEPAGE, E. S. Método padrão sugerido pela IUFRO para ensaios de campo com estacas de madeira. Preservação de Madeiras, São Paulo, v. 1, n. 4, p. 205-216, 1970.

LOW, C. B.; MCKENZIE, H.M.; SHELBOURNE, C. J. A.; GEA, L. D. Sawn timber and wood properties of 21year-old Cupressus lusitanica, C. macrocarpa, and Chamaecyparis nootkatensis x C. macrocarpa hybrids. Part 1: sawn timber performance. New Zealand Journal of Forestry Science, v. 35, n. 1, p. 91-113, 2005.

MARTINS, V. A.; ALVES, M. V. S.; SILVA, J. F.; REBELLO, E. R. G.; PINHO, G. S. C. Umidade de equilíbrio e risco de apodrecimento da madeira em condições de serviço no Brasil. Brasil Florestal, Brasília, v. 22, n. 76, p. 29-34, 2003.

MELO, R. R.; STANGERLIN, D. M.; SANTINI, E. J.; HASELEIN, C. R.; GATTO.D. A.; SUSIN, F. Durabilidade natural da madeira de três espécies florestais em ensaios de campo. Ciência Florestal, Santa Maria, v. 20, n. 2, p. 357-365, 2010.

MOHAREB, A.; SIRMAH, P.; DESHARNAIS, L.; DUMARÇAY, S.; PÉTRISSANS, M.; GÉRARDIN, P. Effect of extractives on conferred and natural durability of Cupressus lusitanica heartwood. Annals of Forest Science, v. 67, p. 504-504, 2010.

OKINO, E. Y. A.; PASTORE, T. C. M.; CAMARGOS, J. A. A.; ALVES, M. V. S.; SANTOS, P. H. O.; TEIXEIRA, D. E.; SANTANA, M. A. E. Color variation of rubberwood clones and cypress infected by Gloeophyllum striatum and Phanerochaete chrysosporium. International Biodeterioration \& Biodegradation, Birmingham, v. 63, p. 41-45, 2009.

OKINO, E. Y. A.; SANTANA, M. A. E.; ALVES, M. V.; MELO, J. E.; CORADIN, V. T. R.; SOUZA, M. R.; TEIXEIRA, D. E.; SOUSA, M. E. Technological characterization of Cupressus spp. wood. Floresta e Ambiente, Seropédica, v. 17, n. 1, p. 1-11, 2010

RITTER, M. A.: MORRELL, J. J. Chapter 13: Bridge Inspection for Decay and Other Deterioration. In: RITTER, M. A. Timber Bridges: Design, Construction, Inspection and Maintenance. United States Department of Agriculture, USDA. Forest Service.Washington, p. 721-787, 1990.

SCHEFFER, T. C.; MORRELL, J. J. Natural durability of wood: a worldwide checklist of species. Forest Research Laboratory, Oregon State University. Research Contribution 22. 1998, 62p.

FLORESTA, Curitiba, PR, v. 50, n. 3, p. 1603 - 1612, jul/set 2020.

Vivian, M. A. et.al.

ISSN eletrônico 1982-4688 
SHIMIZU, J. Y.; RIBAS JÚNIOR, U.; CANCELA, K. C.; MAIOCHI, R. A. Cedrinho como Alternativa para Produção de Madeira em Pequenas Propriedades Rurais. Embrapa Florestas, Colombo, PR, dez. 2006. 3p. (Comunicado Técnico, 172).

VIVIAN, M. A.; SANTINI, E. J.; MODES, K. S.; CARVALHO, D. E.; MORAIS, W. W. C. Resistência biológica da madeira tratada de duas espécies de Eucalyptus em ensaio de campo. Pesquisa Florestal Brasileira, Colombo, v. 34, n. 80, p. 425-433, 2014.

YEH, T.; BRAUN, J. L.; GOLDFARB, B.; CHANG, H.; KADLA, J. F. Morphological and chemical variations between juvenile wood, mature wood and compression wood of loblolly pine (Pinus taeda L.). Holzforchung, v. 60, n. 1, p. 1-8, 2006. 